$\begin{array}{ll}\text { Abstracta Iranica } & \begin{array}{l}\text { Abstracta Iranica } \\ \text { Revue bibliographique pour le domaine irano-aryen }\end{array} \\ & \text { Volume } 22 \mid \mathbf{2 0 0 1} \\ & \text { Comptes rendus des publications de } 1999\end{array}$

\title{
Chardin le Persan. Paris, Fayard, 1998, 568 p.
}

\section{Francis Richard}

\section{OpenEdition}

Journals

Édition électronique

URL : http://journals.openedition.org/abstractairanica/36599

DOI : 10.4000/abstractairanica.36599

ISSN : 1961-960X

Éditeur :

CNRS (UMR 7528 Mondes iraniens et indiens), Éditions de l'IFRI

Édition imprimée

Date de publication : 15 mai 2001

ISSN : 0240-8910

\section{Référence électronique}

Francis Richard, "Chardin le Persan. Paris, Fayard, 1998, 568 p. », Abstracta Iranica [En ligne], Volume 22 | 2001, document 253, mis en ligne le 15 février 2010, consulté le 13 octobre 2020. URL : http:// journals.openedition.org/abstractairanica/36599; DOI : https://doi.org/10.4000/abstractairanica. 36599

Ce document a été généré automatiquement le 13 octobre 2020

Tous droits réservés 


\section{Chardin le Persan. Paris, Fayard, 1998, $568 \mathrm{p}$.}

\section{Francis Richard}

Pour la première fois, le fameux voyageur Jean Chardin (1643-1713), qui séjourna en Perse de 1665 à 1668 puis du début de 1673 à 1677, et publia en 1671 le Couronnement de Soleïmaan puis, à partir de 1686, ses Voyages, fait l'objet d'une véritable biographie. La personnalité de Chardin apparaît dans toute sa singularité : ses dons d'observation et d'analyse ; ses capacités pour le commerce ; sa vie familiale et son ascension sociale. Le livre de D. Van der Cruysse, spécialiste de littérature française du $17^{\mathrm{e}}$ et $18^{\mathrm{e}} \mathrm{s}$., s'appuie sur une documentation considérable, souvent inédite, et est le résultat de recherches dans divers fonds d'archives européens. Désormais, il ne sera plus possible de parler de Chardin de la même façon; la fin de sa vie, à partir de son exil en Angleterre, est révélée dans toute son extrême fécondité. Mais, le biographe n'étant pas iranologue, il reste certainement à reprendre et à compléter la "période persane » de la biographie de Chardin, comme M. Haneda a commencé à faire pour la Description d'Ispahan. Mais on ne pourra plus le faire sans avoir lu avec profit Chardin le Persan, qui livre une partie des clés nécessaires au chercheur.

INDEX

Thèmes : 4.2.1. Safavides et Qâjârs 
AUTEURS

FRANCIS RICHARD

Bibliothèque nationale de France - Paris 